\title{
SCN1A exon 26 variants in epilepsy and migraine patients
}

\author{
Nova Dian Lestari ${ }^{1 *}$, Endang Mutiawati ${ }^{1}$, Ahmad Hamim Sadewa ${ }^{2}$, Hasan Sjahrir ${ }^{3}$, \\ Syahrul', Dessy Rakhmawati Emril' ${ }^{1}$, Harapan Harapan ${ }^{1}$ \\ ${ }^{1}$ Department of Neurology, Faculty of Medicine, Universitas Syiah Kuala, Banda Aceh, \\ ${ }^{2}$ Department of Biochemistry, Faculty of Medicine, Public Health and Nursing, Universitas \\ Gadjah Mada, Yogyakarta, ${ }^{3}$ Department of Neurology, Faculty of Medicine, Universitas \\ Sumatera Utara, Medan, Indonesia
}

DOI: http://dx.doi.org/10.19106/JMedScie/005004201806

\section{ABSTRACT}

Epilepsy and migraine are common neurological diseases in many populations. Mutation of the voltage gated natrium channel Nav1.1 (SCN1A) are important causes of different genetic epilepsies and can also cause familial hemiplegic migraine (FHM-III). This study aimed to identify SCN1A gene variation in patients with epilepsy and common migraine. Gene variation analysis of exon 26 of the SCN1A gene was carried out in 33 patients with epilepsy, 33 patients with migraine and 30 control individuals from Neurology Polyclinic at Dr. Zainoel Abidin General Hospital, Banda Aceh. The PCR and direct sequencing methods were performed in this study. SCN1A gene variations were identified in two epilepsy patients. These gene variations located at exon 26 were four silent mutations in patient E27 at position A4440T (Leu1480Leu), T4443C (Leu1481Leu), A5046G (Leu1682Leu) and C5121T (Asp1707Asp). One silent mutation in patient E30 at position G5505A (Glu1835Glu). None of these gene variations were identified in controls and patients with common migraine in this study. This study has identified 5 genetic variations of SCN1A in patients with epilepsy but not in common migraine. The mechanism and relationship between these variants and epilepsy need to be clarified.

\section{ABSTRAK}

Epilepsi dan migrain adalah penyakit neurologis yang umum di banyak populasi. Mutasi voltage gated natrium channel (SCN1A) adalah penyebab penting dari berbagai epilepsi genetik dan juga dapat menyebabkan migrain hemiplegik familial (FHM-III). Penelitian ini bertujuan untuk mengidentifikasi variasi gen SCN1A pada pasien dengan epilepsi dan migrain umum. Analisis variasi gen ekson 26 dari gen SCN1A dilakukan pada 33 pasien epilepsi, 33 pasien migrain dan 30 orang kontrol dari Poliklinik Neurologi di Rumah Sakit Umum Dr. Zainoel Abidin, Banda Aceh. PCR dan metode direct sequencing dilakukan dalam penelitian ini. Variasi gen SCN1A diidentifikasi pada dua pasien epilepsi. Variasi gen tersebut terletak pada ekson 26 dimana empat mutasi diam pada pasien E27 pada posisi A4440T (Leu1480Leu), T4443C (Leu1481Leu), A5046G (Leu1682Leu) dan C5121T (Asp1707Asp). Satu mutasi diam pada pasien E30 pada posisi G5505A (Glu1835Glu). Tidak satu pun dari variasi gen tersebut teridentifikasi pada kontrol dan pasien dengan migrain umum dalam penelitian ini. Studi ini telah mengidentifikasi 5 variasi genetik SCN1A pada pasien dengan epilepsi tetapi tidak pada migrain umum. Mekanisme dan hubungan antara varian dan epilepsi ini perlu diklarifikasi.

Keywords: epilepsy - gene variation - migraine - mutation - SCN1A 


\section{INTRODUCTION}

The SCN1A gene encodes the alpha subunit of a sodium channel called NaV1.1. which controls the flow of sodium ions into cells (neuron). In the central nervous system, NaV1.1 channels is involved in transmitting signals from one nerve cell to another. The influx of sodium ions through NaV1.1 channels lead to depolarization of neuron and release of neurotransmitters into synaptic cleft. ${ }^{1}$ Thus, voltage gated sodium channel is essential for the generation of cellular excitability.

Recently, this channel was studied as a target of antiepileptic drugs since its mutations are important causes of genetic epilepsy syndrome. ${ }^{2}$ The SCN1A (NaV1.1) is one of the gene which is most clinically relevant epilepsy (MIM\#182389) with hundreds of mutations reported thus far in different genetic epilepsy syndromes characterized by variable phenotypes. $^{3}$ Mutation of this channel is also reported to cause some familial hemiplegic migraine (FHM-type III; MIM\#609634). Familial hemiplegic migraine (FHM) is a rare severe autosomal dominant inherited subtype of migraine with aura characterized by hemiparesis during the attacks. Some FHM families carry missense NaV1.1 mutations, in some cases without any signs of epileptic phenotypes. ${ }^{4}$

The missense mutations change an amino acid in the Nav1.1 channel, which alters the channel's structure and function. The abnormal channels stay open longer than usual, which increases the flow of sodium ions into neurons. This increase triggers the cell to release more neurotransmitters. ${ }^{5}$ However, interpretation of genetic variant is challenging, especially in multifactorial diseases like epilepsies and common migraine. This study aimed to identify SCN1A gene variation in patients with epilepsy and migraine.

\section{MATERIALS AND METHODS}

\section{Sample characteristic}

Genetic analysis was performed in 33 epilepsy patients (16 women and 17 men). Of all patients, 4 were generalized epilepsy and 29 were partial secondary generalized epilepsy. Thirty three migraine patients (27 women and 6 men) were involved included 16 patients without aura (MO) and with aura (MA). In addition, 30 individuals (without epilepsy or migraine) from Policlinic of Neurology, Dr. Zainoel Abidin General Hospital, Banda Aceh were recruited as control. Written informed consent was obtained from each subject involved in the study. Protocol of the study was approved by the Research Ethics Committee, Faculty of Medicine, Universitas Sumatera Utara, Medan, Indonesia in compliance with the national legislation and the code of ethical principles for Medical Research involving human subjects of the World Medical Association. Venous bloods were drawn from all subjects after an informed consent obtained.

\section{Molecular analysis}

Genomic DNA extracted from peripheral blood leukocytes using standard salting-out method. Hot spot mutation of this gene, exon 26, was divided into 3 fragments and amplified by polymerase chain reaction (PCR) followed by a direct sequencing using an ABI BigDye terminatorcycle sequencing kit (Applied Biosystems). The primer used in this study were fragment A forward (F) 5'AGG ACT CTG AAC CTT ACC TTG -3', reverse (R) 5'- TAC ATG TTC ACC ACA ACC AGG -3' ; fragment B (F) 5'- TAA CCC TGG AAG CTC AGT TAA G -3', (R) 5'- TGA TTG GCT GAT AGG AGA CCT T -3'; fragment C (F) 5' - TTG CTT TTA CAA AGC GGG TTC T -3' ; (R) 5' - GTT TGC TGA CAA GGG GTC AC -3'. 


\section{RESULTS}

SCN1A heterozygous gene variations were identified in two epilepsy patients. These gene variations located exon 26 were four silent mutations in patient E27 (a man, 32 years old with epilepsy partial secondary generalized) at position 4440 causing silent mutation codon 1480 CTA $\rightarrow$ CTT (Leu1480Leu), at potition 4443 silent mutation codon $1481 \mathrm{CTT} \rightarrow$ CTC (Leu1481Leu), nucleotide change also at position 5046 causing silent mutation codon $1682 \mathrm{CTA} \rightarrow$ CTG (Leu1682Leu) and nucleotide change at position 5121 causing silent mutation codon 1707 AAC $\rightarrow$ AAT (Asp1707Asp). One silent mutation in patient E30 (a woman, 19 years old with epilepsy partial secondary generalized) at position 5505 causing silent mutation codon 1835 GAG $\rightarrow$ GAA (Glu1835Glu). None of these gene variations were identified in controls and common migraine patients in this study.

\section{DISCUSSION}

Unlike some disorders where mutations are largely concentrated in 'hot spots', the mutations within SCN1A are widely distributed throughout the gene. ${ }^{6,7}$ Only exon 26 was sequenced in this study because of exon 26 is longer than other SCN1A exons and data from previous studies in Indonesian patients reported that mutation in exon 26 were more frequent. ${ }^{8}$ Some experiment have done to prove mutation of gene SCN1A in epilepsy or migraine patients. Mulley et al. ${ }^{6}$ stated that of all the known epilepsy genes, SCN1A was the most clinically relevant, with the largest number of epilepsy-related mutations characterized to that time. Escayg et al. ${ }^{9}$ identified 2 missense mutations. The mutant residues thr875 (see182389.0002) and $\arg 1648$ (see182389.0001) are located in the S4 transmembrane segments of the sodium channel alpha-subunit, which is comprised of 4 homologous domains (D1D4), each containing 6 transmembrane segments. Orrico et al..$^{10}$ identified 21 mutations, including 14 novel mutations, in the SCN1A gene in $22(14.66 \%)$ of 150 Italian pediatric patients with epilepsy. SCN1A mutations were found in $21.2 \%$ of patients with (generalized epilepsy with febrile seizure plus) GEFS+ and in $75 \%$ of patients with Dravet syndrome from the overall patient cohort. Mutation in the SCN1A gene can cause a spectrum of earlyonset epileptic encephalopathies (EIEE6;607208), with the most common designation being Dravet syndrome. ${ }^{9}$ In 14 patients, including a pair of monozygotic twins, with classic symptoms of severe myoclonic epilepsy in infancy (SMEI), Sugawara et al. ${ }^{11}$ identified 10 heterozygous mutations in the SCN1A gene. There were 3 frame-shift mutations which resulted in intragenic stop codons and truncated channels, and 7 nonsense mutations which also resulted in truncated channels. In 29 patients with SMEI and 11 patients with other types of epilepsy, Ohmori et al..$^{12}$ performed a mutation search of the SCN1A gene. They detected mutations in 24 of the 29 patients with SME, but none of the patients with other types of epilepsy. The mutations included deletions, insertions, missense changes, and nonsense changes. They could not find SCN1A mutations in any of the parents, suggesting that de novo mutation in the SCN1A gene occurred in the course of meiosis in the parents. ${ }^{12}$ Claes et al. ${ }^{13}$ investigated 9 patients with Dravet syndrome and observed 8 coding and 1 non-coding mutation in the SCN1A gene. In contrast to a previous study of 7 isolated patients, most mutations were found to be missense mutations clustering in the S4-S6 region of SCN1A. These findings demonstrated that de novo mutations in $\mathrm{SCN} 1 \mathrm{~A}$ are a major cause of isolated Dravet syndrome. ${ }^{13}$ In 7 of 10 unrelated patients with intractable childhood epilepsy with generalized tonicclonic seizures, a variant of Dravet syndrome without myoclonus, Fujiwara et al. . $^{\text {identified }}$ heterozygous mutations in the SCN1A gene. All of the mutations were missense 
mutations. The findings extended the phenotypic spectrum associated with mutations in the SCN1A gene. ${ }^{5}$ Zucca et al. ${ }^{14}$ identified 13 mutations, including 12 novel mutations, in the SCN1A gene in $12(20 \%)$ of 60 unrelated patients with cryptogenic epilepsy beginning in the first 2 years of life. Depienne et al. ${ }^{15}$ identified pathogenic mutations or deletions, including 161 novel point mutations, in the SCN1A gene in 242 (73\%) of 333 patients with Dravet syndrome. The most common mutations were missense $(42 \%)$, and 14 patients had micro arrangements in or deletions of the gene. Thus, the disease mechanism appeared to be haploin sufficiency of the SCN1A gene. Mutations were scattered throughout the gene, and there were no apparent genotype/ phenotype correlations..$^{15}$ Orrico et al. ${ }^{10}$ identified 21 mutations, including 14 novel mutations, in the SCN1 A gene in 22 (14.66\%) of 150 Italian pediatric patients with epilepsy. SCN1A mutations were found in $21.2 \%$ of patients with GEFS+ and in $75 \%$ of patients with Dravet syndrome from the overall patient cohort. Tate et al. ${ }^{16}$ identified a G-to-A polymorphism in the SCN1A gene (rs3812718;182389.0016) that affects alternative splicing of exon 5. The major A allele disrupts the consensus sequence of the fetal/neonatal exon 5N, reducing the expression of this exon relative to the adult exon 5A. Two antiepileptic drugs, carbamazepine and phenytoin, act by binding to the alpha-subunit of neuronal sodium channels encoded by SCN1A. ${ }^{16}$ The findings emphasized an emerging role of genetic polymorphisms in modulation of drug effect, and illustrated the importance of considering the activity of compounds at alternative splice forms of drug targets. ${ }^{17}$ Mulley et al. ${ }^{6}$ found that the more than 100 epilepsyassociated mutations reported in the SCN1A gene to that time were spread throughout the gene. Some clustering of mutations was observed in the $\mathrm{C}$ terminus and the loops between segments 5 and 6 of the first 3 domains of the protein. Kanai et al. ${ }^{18}$ performed a meta analysis of the physiochemical effects of amino acid substitutions resulting from missense mutations in the SCN1A gene and their phenotypes in order to assess genotype/ phenotype correlations. From 33 articles, they studied 155 missense mutations, including 22 associated with GEFS+, 14 associated with an intermediate phenotype (e.g., T1709I;182389.0013), and 119 associated with a severe phenotype. ${ }^{18}$ Herini et al. ${ }^{8}$ identified two novel SCN1A mutations in Indonesian children diagnosed as having SMEI and SMEB (Severe myoclonic epilepsy in infancy borderline), there were at nucleotide 4834 (c.4834G $>$ A) in exon 25 leading to substitution of valine with isoleucine at at amino acid position 1612 (p.V1612I) and at nucleotide 5266 (c.5266T $>\mathrm{G}$ ) in exon 26 leading to substitution of cysteine with glycine at amino acid 1756 (p.C1756G). ${ }^{8}$ In our study, SCN1A gene variations were identified in two epilepsy patients. These gene variations located at exon 26 were four silent mutations in patient E27 at position A4440T (Leu1480Leu), T4443C (Leu1481Leu), A5046G (Leu1682Leu) and C5121T (Asp1707Asp). One silent mutation in patient E30 at position G5505A (Glu1835Glu). None of these gene variations were identified in controls and common migraine patients in this study. This study has identified 5 genetic variations of SCN1A in patients with epilepsy but not in common migraine. The mechanism and relationship between these variants and epilepsy need to be clarified. But, may be it happen because of reducing sodium currents in GABAergic inhibitory interneurons resulting from heterozygous SCN1A mutations that may cause the hyperexcitability that leads to epilepsy. ${ }^{19}$ The majority of SCN1A mutations cluster in the $\mathrm{C}$-terminus and the pore loops in the first three domains of the protein. ${ }^{6}$ The pathophysiology of SCN1A mutations is a decrease in the activity of GABAergic inhibitory neurons. For example, most of the mutations that cause Dravet syndrome (SMEI) result in loss of function, whereas mutations that cause GEFS + are missense, 
likely altering channel activity. ${ }^{9}$ Ogiwara et $a l .{ }^{20}$ concluded that haplo insufficiency of the SCN1A gene underlies seizures. This study has identified no genetic variations of SCN1A in patients with common migraine. Mutation of SCN1A commonly found in patients with familial hemiplegic migraine. In affected members of 3 European families with familial hemiplegic migraine-3 (609634), Dichgans et $a l .^{21}$ identified a heterozygous $4465 \mathrm{C}-\mathrm{A}$ transversion in exon 23 of the SCN1A gene, resulting in a gln1489-to-lys (Q1489K) substitution in the cytoplasmic linker between domains III and IV, which is critical for fast inactivation. Dichgans et al. ${ }^{21}$ suggested that the mutation may facilitate initiation and propagation of cortical spreading depression, which is thought to be related to migraine aura. FHM-III mutation accelerates recovery from fast inactivation of $\mathrm{Na}(\mathrm{V}) 1.5 \quad$ (presumably $\mathrm{Na}(\mathrm{V}) 1.1$ ) channels. SCN1A mutation has effects on the gating properties of neuronal voltage-gated $\mathrm{Na}(\mathrm{V}) 1.1 \mathrm{Na}+$ channel consistent with both hyperexcitability and hypoexcitability. This self-limited capacity may be a specific characteristic of migraine mutations..$^{22}$ Some FHM-III mutations resulted in gain of function (familial hemiplegic migraine and generalized epilepsy) such as L263V and L1649Q, but some mutations resulted in loss of function (typical familial hemiplegic migraine) such as Q1489K. These results emphasize that migraine and epilepsy may share common molecular mechanisms. ${ }^{23}$ The T1174SSCN1A mutation can lead to a gain of function in some conditions and loss of function in other conditions. These findings may help to explain the coexistence of epilepsy and familial hemiplegic migraine without epilepsy in the same family. ${ }^{22}$ Bioinformatics analysis of the 3 familial hemiplegic migraine mutations shows that FHM-III is more resistant to mutation within the amino acid sequence when compared with others. ${ }^{24}$ This expanded list of mutations, taken together with those reviewed by Mulley et al. ${ }^{6}$ provides an essential mutational database for use as an interpretative aid for diagnostic laboratories offering SCN1A mutation testing.

\section{CONCLUSION}

This study has identified 5 genetic variations of SCN1A in two patients with epilepsy but not in common migraine. The mechanism and relationship between these variants and epilepsy need to be clarified.

\section{ACKNOWLEDGEMENTS}

We would like to express our sincere appreciation to all patients for their contribution. This study was support by Indonesian Directorate of Research and Community Service, grant number 025/ SP2H/LT/DRPM/II/2016.

\section{REFERENCES}

1. Meisler MH, Kearney JA. Sodium channel mutations in epilepsy and other neurological disorders. J Clin Invest 2005; 115(8):2010-7.

http://dx.doi.org/10.1172/JCI25466

2. Catterall WA, Kalume F, Oakley JC. Nav1.1 channels and epilepsy. J Physiol 2010;588(Pt 11):1849-59.

http://dx.doi.org/10.1113/jphysiol.2010.187484

3. Guerrini R, Marini C, Mantegazza M. Genetic epilepsy syndromes without structural brain abnormalities: clinical features and experimental models. Neurotherapeutics 2014;11(2):269-85. http://dx.doi.org/10.1007/s13311-014-0267-0

4. Vecchia D, Tottene A, van den Maagdenberg AM, Pietrobon D. Mechanism underlying unaltered cortical inhibitory synaptic transmission in contrast with enhanced excitatory transmission in CaV2.1 knockin migraine mice. Neurobiol Dis 2014;69:225-34.

http://dx.doi.org/10.1016/j.nbd.2014.05.035

5. Fujiwara T. Clinical spectrum of mutations in SCN1A gene: severe myoclonic epilepsy in infancy and related epilepsies. Epilepsy Res 
2006;70(Suppl 1):223-30.

http://dx.doi.ong/10.1016/j.eplepsyres.2006.01.019

6. Mulley JC, Scheffer IE, Petrou S, Dibbens LM, Berkovic SF, Harkin LA. SCN1A mutations and epilepsy. Hum Mutat 2005;25(6):535-42. http://dx.doi.org/10.1002/humu.20178

7. Sun H, Zhang Y, Liu X, Ma X, Yang $\mathrm{Z}$, Qin $\mathrm{J}$, et al. Analysis of SCN1A mutation and parental origin in patients with Dravet syndrome. J Hum Genet 2010;55(7):421-7.

http://dx.doi.org/10.1038/jhg.2010.39

8. Herini ES, Gunadi, Van kempen MJ, Yusoff S, Sutaryo, Sunartini, et al. Novel SCN1A mutations in Indonesian patients with severe myoclonic epilepsy in infancy. Pediatr Int 2010; 52(2):234-9. http://dx.doi.org/10.1111/j.1442-200X.2009.02916.x

9. Escayg A, MacDonald BT, Meisler MH, Baulac S, Huberfeld G, An-Gourfinkel I, et al. Mutations of SCN1A, encoding a neuronal sodium channel, in two families with GEFS+2 Nat Genet 2000;24(4):343-5. http://dx.doi.org/10.1038/74159

10. Orrico A, Galli L, Grosso S, Buoni S, Pianigiani R, Balestri P, et al. Mutational analysis of the SCN1A, SCN1B and GABRG2 genes in 150 Italian patients with idiopathic childhood epilepsies. Clin Genet 2009;75(6):579-81. http://dx.doi.org/10.1111/j.1399-0004.2009.01155.x

11. Sugawara T, Miyazaki ME, Fukushima K, Shimomura J, Fujiwara T, Hamono $\mathrm{S}$, et al. Frequent mutations of SCN1A in severe myoclonic epilepsy in infancy. Neurology 2002;58(7):1122-4.

http://dx.doi.org/10.1212/WNL.58.7.1122

12. Ohmori I, Ouchida M, Ohtsuka Y, Oka E, Shimizu K. Significant correlation of the SCN1A mutations and severe myoclonic epilepsy in infancy. Biochem Biophys Res Commun2002;295(1):17-23. http://dx.doi.org/10.1016/S0006-291X(02)00617-4

13. Claes L, Del-Favero J, Ceulemans B, Lagae L, Van Broeckhoven C, De Jonghe $\mathrm{P}$. De novo mutations in the sodium-channel gene SCN1A cause severe myoclonic epilepsy of infancy.
Am J Hum Genet2001;68(6):1327-32. http://dx.doi.org/10.1086/320609

14. Zucca C,Redaelli F, Epifanio R, Zanotta $\mathrm{N}$, Romeo A, Lodi M, et al. Cryptogenic epileptic syndromes related to SCN1A: twelve novel mutations identified. Arch Neurol 2008;65(4):489-94.

http://dx.doi.org/10.1001/archneur.65.4.489

15. Depienne C, Trouillard O, Saint-Martin C, Gourfinkel-An I, Bouteiller D, Carpentier W, et al. Spectrum of SCN1A gene mutations associated with Dravet syndrome: analysis of 333 patients. J Med Genet 2009;46(3):183-91. http://dx.doi.org/10.1136/jmg.2008.062323

16. Tate SK, Depondt C, Sisodiya SM, Cavalleri GL, Schorge S, Soranzo $\mathrm{N}$, et al. Genetic predictors of the maximum doses patients receive during clinical use of the anti-epileptic drugs carbamazepine and phenytoin. Proc Natl Acad Sci USA 2005;102(15):5507-12. http://dx.doi.org/10.1073/pnas.0407346102

17. Thompson $\mathrm{CH} 1$, Kahlig KM, George AL Jr. SCN1A splice variants exhibit divergent sensitivity to commonlyused antiepileptic drugs. Epilepsia 2011;52(5):1000-9.

http://x.doi.org/10.1111/j.1528-1167.2011.03040x

18. Kanai K, Yoshida S, Hirose S, Oguni $\mathrm{H}$, Kuwabara S, Sawai S, et al. Physicochemical property changes of amino acid residues that accompany missense mutations in SCN1A affect epilepsy phenotype severity. J Med Genet 2009;46(10):671-9.

http://dx.doi.org/10.1136/jmg.2008.060897

19. Yu F, Mantegazza M, Westenbroek RE, Robbins CA, Kalume F, Burton KA, et al. Reduced sodium current in GABAergic interneurons in a mouse model of severe myoclonic epilepsy in infancy. Nature Neurosci 2006;9(9):1142-9.

http://dx.doi.org/10.1038/nn1754

20. Ogiwara I, Miyamoto H, Morita N,Atapour N, Mazaki E, Inoue I, et al. $\mathrm{Na}(\mathrm{v}) 1.1$ localizes to axons of parvalbumin-positive inhibitory interneurons: a circuit basis for epileptic seizures in mice carrying an 
Scn1a gene mutation. J Neurosci 2007; 27(30):5903-14. http://dx.doiorg/10.1523/NEUROSCI5270-062007

21. Dichgans $M$, Freilinger T, Eckstein G, Babini E, Lorenz-Depiereux B, et al. Mutation in the neuronal voltage-gated sodium channel SCN1A in familial hemiplegic migraine. Lancet 2005; 366(9483):371-7. http://x.doi.org/10.1016/S0140-6736(05)66786-4

22. Cestèle S, Labate A, Rusconi R, Tarantinol P, Mumoli L, Franceschetti $\mathrm{S}$, et al. Divergent effects of the
T1174S SCN1A mutation associated with seizures and hemiplegic migraine. Epilepsia 2013;54(5):927-35. http://dx.doi.org/10.1111/epi.12123

23. Pietrobon D. Familial hemiplegic migraine. Neurotherapeutics 2007;4(2):274-84. http://dx.doi.org/10.1016/j.nurt.2007.01.008

24. Wiwanitkit V. FHM3 in familial hemiplegic migraine is more resistant to mutation than FHM1 and FHM2. J Neurol Sci 2009; 277(1-2):76-9.

http://dx.doi.org/10.1016/j.jns.2008.10.012 